HISTORIA: Jurnal Pendidik dan Peneliti Sejarah, 5(1), 57-64. https://doi.org/10.17509/historia.v5i1.39181

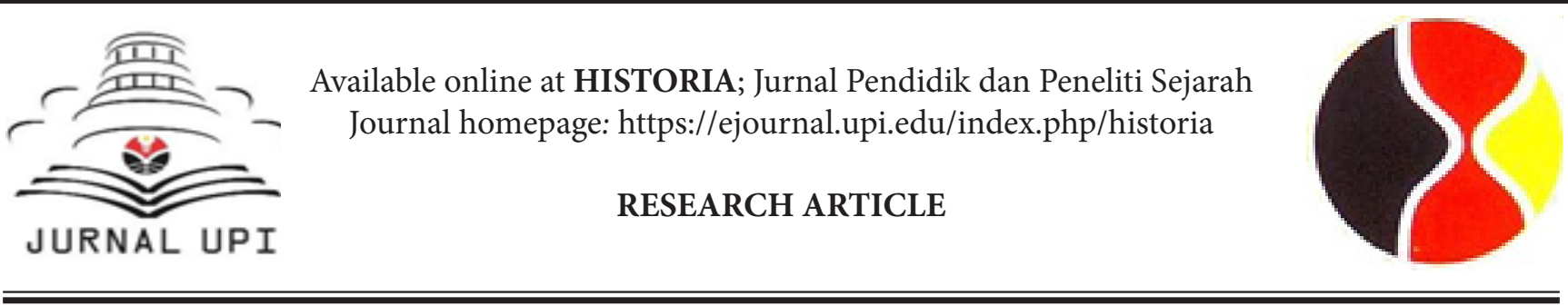

\title{
RE-ESTIMATING THE SIZE OF JAVANESE JONG SHIP
}

\author{
Muhammad Averoesi \\ Department of Mechanical Engineering, Engineering faculty, Brawijaya University \\ Correspondence: Veros4444@student.ub.ac.id.
}

To cite this article: Averoes, M. (2022). Re-Estimating the Ssize of javanese jong ship. HISTORIA: Jurnal Pendidik dan Peneliti Sejarah, 5(1), 57-64. https://doi.org/10.17509/historia.v5i1.39181.

Naskah diterima : 2 Oktober 2020, Naskah direvisi : 20 Oktober 2021, Naskah disetujui : 30 Desember 2021

\begin{abstract}
It is known that the Javanese jong ship is larger than Portuguese ships. There have been several scholars who have estimated the size of the jong ship, though in an unspecified manner. This study is intended to estimate the size of the jong ship by calculation. This paper explores historical records of jong sizes, claims of jong sizes, and calculates jong sizes with formulas according to shipbuilding rules. From the calculations carried out, the size of the Javanese jong is obtained. The results of this calculation reject and confirm the jong size research that has been done by other scholars, the claim that the jong can reach more than $300 \mathrm{~m}$ is rejected by the results of the calculations that have been carried out.
\end{abstract}

Keywords : Javanese jong,; Junk ship; Majapahit jong. 


\section{INTRODUCTION}

Jong or Javanese junk is a transport and merchant ship used by the ancient Javanese people and other ethnicities in the archipelago. The Javanese jong ship is thought to have appeared at least around the 9th century $\mathrm{AD}$. In the past, it was known that the K'un-lun po (or K'un-lun bo) ship used a different connection technique than the jong. The size of the po ship (length, height, number of passengers and tonnage) is known from Chinese records, while the dimensions of the Javanese jong ship is not usually stated except in the records of Bujangga Manik. Even so, Bujangga Manik's notes do not mention the size of the tonnage and the number of passengers, so it is still ambiguous whether the type of that jong is small, medium, or large.

Pierre-Yves Manguin (1980) pointed out that the tonnage of the jong of early 16th century was considerable, at least by the European standard of that time. Manguin obtained an average tonnage of 350 to 500 tons deadweight, and the largest occasionally carried 1000 men onboard, with 1000 tons deadweight according to his estimate. With such size, a jong is said to be larger than Portuguese largest ship. An encounter with a jong off the coast of Samudra Pasai recorded that the deck of the jong was higher than the tall aft-castle of Portuguese flagship, the Flor de la Mar (Manguin, September 1993a: 266).

Irawan Djoko Nugroho has tried to estimate the length of the Jong. He estimated the jong of Pati Unus, which carried 1000 men on board. Nugroho thought that the Flor de la Mar has a size of more than 69 meter, with a possibility of $78.3 \mathrm{~m} \mathrm{LOA}$. Nugroho estimated that a Javanese jong would have a length, width, and height of 4 to 5 times the dimensions of Flor de la Mar (Nugroho, 2011: 304-307). From engineering point of view, this size is manifestly absurd, a wooden ship of 19th century, with all the modern technology available, did not reach such size. Because of this, analytical calculation is needed to confirm or deny the claim.

\section{METHOD}

The research methods used in this study are: 1) Data collection. These data are taken from historical records regarding jong, and claims or estimations regarding jong sizes. 2) Determine the formula used. The formula used to estimate the dimensions of the jong is determined in this stage, by comparing it with existing ship size calculations and also determining it from the historical records that have been collected. 3) Calculation. At this stage, the dimensions of the jong size are calculated based on the historical data collected. 4) Confirmation of validity. This stage checks the calculation by comparing it with existing records and size claims or estimations.

\section{DISCUSSION}

\section{Known Size}

In 1322 Friar Odoric da Pordenone mentioned that the zuncum ship carried at least 700 sailors and merchants (Yule, 1886). During the second Singapura invasion (1398), Majapahit deployed 300 jong with no less than 200,000 Javanese (Leyden, 1821), indicating that they carried more than 660 men per ship. The jong that was used by Bujangga Manik is said to have a width of 8 depa (12.8-16 m) and a length of 25 depa (40-50 m), but there is no mention of the number of passengers .

For comparison, the size of the K'un lun po ship carrying 600-700 people along with more than 10,000 hu of cargo (which according to Pierre-Yves Manguin was 600 deadweight tons) (Manguin, 1993a), was 20 chang $(52 \mathrm{~m})$ or more in length and 2-3 chang $(5.2-7.8 \mathrm{~m})$ high above the water (Christie, 1957). Yiqiejing Yinyi mentions that the po is a large and fast ocean-going ship, carrying 1000 people and their merchandise, with a length of more than 60 meters (Manguin, 1993a).

The jong ships are known to be of great size, a 600tons Javanese junk encountered by the Albuquerque fleet near Pasai is said to have carried 300 men and larger than the largest Portuguese ship, the Flor do Mar, to the point that the rear castle barely reached the height of the Javanese jong's bridge. The jong that Pati Unus used to attack Portuguese Malacca was carrying 1000 men, said to be so large that the nearby Anunciada did not look like a ship (Cortesão, 1944a). These two reports did not mention the dimensions of the jong.

Philip Bowring estimated that a 30 meter junk would have a tonnage of 150 tons, and that means one with a tonnage of 1000 tons would be 55 meters long. Bowring assumes that the junk encountered near Pasai are close to 50 meters long (Bowring, 2019). Majapahit jong that carried 121 people, with a length of 33 meters estimated to have a deadweight of 220 tons, was used by Chen Yanxiang to visit Korea (Cho, 2009). Irawan Djoko Nugroho estimates the length of the Pati Unus jong is 4-5 times the length of the Flor do Mar, which he interprets as $78.3 \mathrm{~m}$, so the length of the jong would have been 313.2-391.5 m (Nugroho, 2011). From the engineering and shipbuilding perspective, there are several problems that will arise:

a) A ship of this length would have a displacement of more than 140,000 tons, far exceeding the natural size limit of a wooden ship of about 7,000 tons. 
b) With the advantages of modern technology, it is difficult to build a wooden ship weighing 10,000 tons, let alone that 14 times as large. It was only when ships began to be made of iron in the $1860 \mathrm{~s}$ that they could weigh more than 10,000 tons.

c) A ship of this size would need a mast about 100 $\mathrm{m}$ high, several timbers must be held together vertically.

d) A ship has a natural limit to its size: exceeding it will render it structurally unsafe and result in a substantial loss of maneuverability.

e) If the hull is too long, the hull would not withstand the differential pressure caused by the surface wave.

f) It would be surprising if a ship of that size didn't have any structural problems.

g) Beyond a certain size (about $300 \mathrm{ft}$ or $91.44 \mathrm{~m}$ long), a wooden ship is structurally unsafe .

\section{Size Estimations}

Just like Zheng He's treasure ship, no wreck of jong has been found. To estimate the actual size, it can only be done by examining written reports and from existing depictions. According to Manguin, a jong is a type of round ship, which has a ratio of length: width of 3:1 to 4:1 (Manguin, 2012b). Bujangga Manik's jong has a ratio of 3.125:1. For tonnage, the Javanese junk that the Portuguese encountered near Pasai carried 300 people and weighed 600 tons (Birch, 1875), resulting in a passenger:weight ratio of $1: 2$. With this weight, the jong is said to be bigger and taller than the Flor do Mar which has a 400-tons burden. According to Manguin, the jong's weight is deadweight, not burden (Manguin, 1993a). Assuming a conversion coefficient of $5 / 3$, a round ship with a deadweight of 600 tons will have a burden of 1000 tons and a displacement of 1667 tons. This makes more sense than considering the 600 tons as burden.

To find out the dimensions, it can be done by knowing the displacement first. Displacement is the weight of the volume of water displaced by the ship below the surface. Using the Xin Yuan'ou formula, to calculate displacement one needs to know the length, width, and draft of the ship, as well as an accurate idea of what coefficients to use. Displacement in tons is calculated by multiplying the length, width, and draft together (as long as this is expressed in meters and is on the waterline) and then multiplying the product by a coefficient of about 0.5 in the case of Chinese junks (Church, 2005).

The dimensions of the upper part of the ship above water with the part in contact with the water is a further problem. By comparing Johann Theodor de Bry's depiction of a jong, it can be assumed that the length of the hull on the waterline is 0.762 of the LOD. The bowsprit is estimated to protrude above the water for a length of $10 \%$ greater than the LOD. The width of the ship is assumed to be $1 / 3-1 / 4$ from LOD, the calculation is using interpolation, the larger the ship, the leaner ratio is used, with a lower limit for ships weighing 40 tons (jong used by Banten) and the upper limit for Majapahit and Pati Unus' jong. As for the ship's draft, this is the most difficult to find information on, the jong's $\mathrm{V}$ hull construction will make it relatively deep compared to the Chinese junks. Therefore the draft of the ship is only assumed, and also using the interpolation formula between different sizes. In this case, a draft of $3 \mathrm{~m}$ is assumed for a 40 tons deadweight jong, and $9 \mathrm{~m}$ is used for 2000 tons jong.

For the next step, we need to know the size range of jong. It is known that jong has been decreased in size since the arrival of the Europeans to the Nusantara archipelago. Manguin, researching from 16th century Iberian sources, concluded that the smallest tonnage figure of jong was 85 tons, with the highest of 700 tons. The average tonnage of this era was 400-500 tons. The Pati Unus' jong, built in Jepara to attack Portuguese Malacca was an exception: It took 3 years to built and carried 1000 men, which Manguin estimated to be 1000 tons deadweight (Manguin, September 1980). In my opinion, this estimate is wrong, a jong with a load of 1000 people will have a deadweight tonnage of 2000 tons, because of the passenger to deadweight ratio which is $1: 2$. This is inferred from the Javanese jong captured by the Portuguese off the coast of Pasai, which carried 300 men and was about 600 tons (Birch, 1875).

This passenger to deadweight tonnage ratio is different from K'un-lun po, which carried 600-700 persons with 10,000 bushels (hu) of cargo, which Manguin estimated to be about 600 tons deadweight (Christie, 1957, Manguin, 1993a). This would give a passenger to tonnage ratio of $1: 1$ to $1: 0.86$. For simplification, we will take 1:1 ratio for the calculations of K'un-lun po dimensions. The smallest passenger capacity of K'unlun po is not directly recorded, but the one boarded by Faxian (Fa-Hsien) was carrying 200 persons on board (Groeneveldt, 1876). The largest K'un-lun po carried 1000 men on board, this would make a deadweight tonnage of 1000 tons.

Then why would the passenger to tonnage ratio was different between K'un-lun po and jong? The reason is because the fastening technique between the two were different. The K'un-lun po utilized a fastening technique called sewn-pland and lashed lug construction. Their hulls were built by raising planks on each side of a keelpiece that shows clear signs of having evolved from a dugout base (thus pointing to a development from an earlier 
simple dug-out canoe). All or part of their components were held together by vegetal stitches or lashings. This technique is known from textual sources to have been in use in early South-East Asia and has survived under a variety of forms in scattered areas over most of the region, from Hainan and Viétnam to the Philippines and Eastern Indonesia, well into the 20th century (Manguin, 1993a). This technique is typically used for small vessels, because lashings might not provide enough structural strength to support vessels of several hundred tons deadweight. Thicker planks would be needed to make larger vessels (Manguin, September 1980, Manguin, 1993a). From a Buddhist record, it is known that adding more layers of planking to the hull would create a sufficient strength to build larger vessels with a capacity of 1000 persons: "With the fibrous bark of the coconut tree, they make cords which bind the parts of the ship together (...). Nails and clamps are not used, for fear that the heating of the iron would give rise to fires. The ships are constructed by assembling several thicknesses of side planks, for the boards are thin and that they fear they would break."(Manguin, 1993a). In jong, the fastening technique used was edge fastening using wooden pegs, dowels, and tenons. They are contructed plank first, the frames would be added later. This kind of fastening appeared in textual and archaeological evidence in the 13/14th century (Manguin, September 1980, Manguin, 1993a). As the ship grows old more planks would be added above the old layer (Stanley, 1866). However, the presence of jongs recorded in 9th century old-Javanese inscription (Reid, 2000: 60) may indicate an earlier appearance.

In the early 1600s, the tonnage of the jong became smaller, the average load was probably about 100 tons deadweight (Manguin, 1993b). During the early voyages of Cornelis de Houtman to Nusantara archipelago (1595-1599), the Dutch observers claimed that they did not see Bantenese jong exceeding 20 lasts (40 tons) (Rouffaer, 1915). But it was clear that the crew did not see the leviathans of Jepara and Semarang, which carried up to 300 to 400 tons of merchandise (Reid, 2000: 79). Manguin argued that that the failure of jong in battles against smaller and more agile Western ships after Pati Unus' expedition to Malacca (1513) may have convinced the Javanese shipbuilders that the large but less agile jong faced too much risk against the European style of naval battle, so the ships they built later were smaller and faster (Manguin, 1993b). Yet if the Javanese jongs were so great and durable, to the point that it attracts the admiration of European writers, why would the Javanese made smaller vessels? From Portuguese reports, it is known that jong was immune to cannon fire, but was said to be defeated easily by the Portuguese. Reid argues that the Portuguese may have only exaggerated their victory (Reid, 2000). Of the dozens of junks, only 3 survived the 1513 attack (Cortesão, 1944b). The tactic used to destroy the junks was not with cannons, but by boarding and burning them (Crawfurd, 1856). The Javanese also have a habit of burning the ship they are traveling on if they feel that a ship will be seized (Birch, 1875). Portuguese tactic in sea battle in 1500-1630 AD was based on short range engagement, which also prioritizes boarding parties and man-to-man fighting. The Portuguese ships of 16th century were lightly armed with cannons for its size (Meilink-Roelofsz, 1962).

The Portuguese themselves were inconsistent in their records: The number of Javanese ships under Pati Unus of Demak attacking Malacca in 1513 recorded by different authors to be about 90-300 ships with 5,00025,000 soldiers. If we take the smallest number (assuming it is not an exaggeration), there are 5,000 people with 40 junks, 60 lancaran, and 100 kelulus (Cortesão, 1944b). This made no sense because 40 of 500-ton junks would carry 10,000 people. The possible numbers of the actual Demak fleet were 10 junks, 15 lancaran, and 25 kelulus. The attack on Melaka was then carried out with leaner ships, such as the lancaran, ghurab, and ghali (Manguin, 2012b and Manguin, 1993b). Jepara attempted to attack Portuguese Melaka in 1574 with 80 jongs weighing up to 400 tons and 220 kelulus, but eventually had to withdraw after supplies ran low, the plague that hit, and 30 junks and boats were burned by the Portuguese at night with firebombs (Monteiro, 2011). Javanese ships became easy targets for Portuguese and Dutch ships that captured them and seized their cargo (Reid, 2000), so they switched to smaller and faster ships. From these points it can be concluded, later jongs was made smaller and faster to avoid boarding and capture by the Portuguese and Dutch, not because of the danger of cannons.

The jongs that were used by Majapahit is even larger than those of earlier eras. During the invasion of Singapura, Majapahit deployed 300 jong with no less than 200,000 Javanese people (Leyden, 1821), indicating that they carried more than 660 men per ship. This might indicate that the average Majapahit jong could have carried 600-700 persons on board. This is supported by Odoric da Pordenone's account (d. 1331). When he was traveling to China in ca. 1322, he mentioned that the zuncum ship carried at least 700 sailors and merchants (Yule, 1886). That means the deadweight tonnage of Majapahit jong would be around 1200-1400 tons. There is no direct record of how big the Majapahit's largest junk is, but taking the data of largest K'un-lun po and Pati Unus' jong, both of which carried 1000 people, the largest 
Majapahit jong may have carried 1000 men on board, or about 2000 tons deadweight. This might be confirmed indirectly by al-Nuwayrī al-Iskandarānīs account, whom between 1365-1372 AD claimed that "Indian" ships had 7 sails (Agius, 2008). The term "India" in this context and era is not restricted to the Indian state, the Republic of India that gained independence in 1947, but the large part of the world spanning from Persia to before China. Niccolò da Conti even considered Java and Sumatra to be part of Central India (Major, 1857). Reports of Khalil ibn Shahin al-Zahiri around 1436-1437 AD, indicated that ships with 7 sails were regular visitors in Jeddah (Starkey, 2007). From comparative study, a vessels of such amount of sail would be the largest ships, that is the 2000 tons jong of Majapahit (Averoes, 2021). The smallest passenger or tonnage of Majapahit jong is not known, so let's just assume a capacity of 50 men or about 100 tons deadweight tons.

Other question may arise: If Majapahit era jongs were that great, why was the jongs in the early 16th century became smaller? Tomé Pires counted that at the beginning of the 16th century in various port cities on the north coast of Java there were about 100 large jongs (Liebner, 2016), in stark contrast to the number of Majapahit jongs that attacked Pasai, that is 400 large jongs (Nugroho, 2011). Manguin argues that the decline of the jong was due to competition with Tamil, Gujarati, and Chinese traders: By the arrival of the Portuguese, trade with the jong had shrunk from previous decades and the furthest destinations had been abandoned, leaving the jongs trading only between south of India to China. (Manguin, 1993b). However, this does not explain how the significant decline occurred. Moreover, Tome Pires explained that the Javanese in 1513 could not make 10 junks in 10 years, and most of the junks came from Pegu to Melaka to be sold (Cortesão, 1944a). Pramoedya Ananta Toer through his work argues that the junks of Majapahit were destroyed during the civil war (Paregreg) because they attacked each other with cetbang (Toer, 1995). There are several things that support his opinion. First, Ma Huan's report which contains Zheng He's travel notes, does not mention the existence of Javanese junks, even though if you look at previous Chinese reports, the Chinese were amazed by the Nusantaran ships and the Chinese were known as good recorders. This may have happened because of the battle between the jong fleets of Western and Eastern palace of Majapahit for control of the spice route from the north of Bali to the Moluccas sea. From the records of Fra Mauro, Niccolò da Conti, and al-Zahiri, it can be seen that there were still survivors that sailed long distances. The inability of the Javanese to make 10 junks in 10 years could be due to the destruction of the shipyards on the north coast of Java. Also, according to Slamet Mulyana, the economy of the country and the people became chaotic due to the Paregreg war. People who were supposed to work in the fields for the benefit of food production were deployed to the battlefield. Ships that were supposed to be used for trade were used to transport soldiers. However, the Paregreg war was not the only civil war in Majapahit: In just 30 years Majapahit was ruled by 6 kings from various families due to internal conflicts (Mulyana, 2005). Because of these setbacks, the Javanese only made cheaper, smaller ships to make up the loss of trade profit. Even with smaller size, the Javanese were struggling to make 10 junks in 10 years in early 16th century, and as such, opted to buy the junks from Pegu (which was sold in Malacca) or bought them in Borneo (from Lawe, Tanjung Pura, and Banjarmasin) (Cortesão, 1944a). Javanese shipping and shipbuilding industry must have been recovered since that, because the Javanese used 80 jong of up to 400 ton size during 1574 attack on Portuguese Malacca (Manguin, 2012b, Manguin, 1993b). All this information should be sufficient to refute Meilink-Roelofsz's statement, whom thinks that Java can only produce small, fast-sailing war proas and cargo ships of small tonnage (Meilink-Roelofsz, 1962).

\section{Calculation}

From the method used above, the size of an early 16th century jong would be:

\begin{tabular}{|c|c|c|c|c|c|c|}
\hline Passenger & $\begin{array}{l}\text { Weight (dead/ } \\
\text { burden/ } \\
\text { displacement) }\end{array}$ & $\begin{array}{c}\text { Width } \\
\text { (waterline) } \\
\text { (m) }\end{array}$ & $\begin{array}{l}\text { Draft } \\
(\mathrm{m})\end{array}$ & $\begin{array}{l}\text { LWL } \\
(\mathrm{m})\end{array}$ & $\begin{array}{l}\text { LOD } \\
(\mathrm{m})\end{array}$ & $\begin{array}{l}\text { LOA } \\
(\mathrm{m})\end{array}$ \\
\hline $42.5 \sim 43$ & $85 / 142 / 236$ tons & 8.08 & 3.14 & 18.62 & 24.43 & 26.87 \\
\hline 200 & $\begin{array}{l}400 / 667 / 1111 \\
\text { tons }\end{array}$ & 14.94 & 4.1 & 36.25 & 47.57 & 52.33 \\
\hline 250 & $\begin{array}{l}500 / 833 / 1389 \\
\text { tons }\end{array}$ & 15.99 & 4.41 & 39.41 & 51.72 & 56.89 \\
\hline 350 & $\begin{array}{l}700 / 1167 / 1944 \\
\text { tons }\end{array}$ & 17.45 & 5.02 & 44.37 & 58.23 & 64.06 \\
\hline
\end{tabular}

Note: The 85 tons deadweight jong is the smallest in this century, 400-500 tons is the average, and 700 tons is the largest (Manguin, September 1980: 267-268). 
For jongs in the early 17 th century:

\begin{tabular}{|c|c|c|c|c|c|c|}
\hline Passenger & $\begin{array}{c}\text { Weight (dead/ } \\
\text { burden/ } \\
\text { displacement) }\end{array}$ & $\begin{array}{c}\text { Width } \\
\text { (waterline) }\end{array}$ & Draft & LWL & LOD & LOA \\
\hline 20 & $\begin{array}{c}40 / 67 / 111 \text { tons } \\
100 / 167 / 278 \\
\text { tons } \\
50\end{array}$ & 5.69 & 3 & 13.01 & 17.07 & 18.78 \\
\hline 50 & $\begin{array}{c}300 / 500 / 833 \\
\text { tons } \\
400 / 667 / 1111 \\
\text { tons }\end{array}$ & 13.56 & 3.8 & 32.37 & 42.48 & 46.73 \\
\hline
\end{tabular}

Note: The smallest jong of this century is 40 tons deadweight (Rouffaer, 1915: 133), 100 tons is the average weight of this century (Manguin, 1993b: 199), while 300 and 400 tons are the largest jongs still remaining in Semarang and Jepara (Reid, 2000: 79).

The size of jong during the Majapahit period (14th to 15 th centuries) was:

\begin{tabular}{|c|c|c|c|c|c|c|}
\hline Passenger & $\begin{array}{l}\text { Weight (dead/ } \\
\text { burden/ } \\
\text { displacement) }\end{array}$ & $\begin{array}{c}\text { Width } \\
\text { (waterline) }\end{array}$ & Draft & LWL & LOD & LOA \\
\hline 50 & $100 / 167 / 278$ tons & 8.7 & 3.18 & 20.08 & 26.36 & 28.99 \\
\hline 600 & $\begin{array}{c}1200 / 2000 / 3333 \\
\text { tons }\end{array}$ & 19.28 & 6.55 & 52.77 & 69.26 & 76.18 \\
\hline 700 & $\begin{array}{c}1400 / 2333 / 3889 \\
\text { tons }\end{array}$ & 19.64 & 7.16 & 55.28 & 72.55 & 79.81 \\
\hline 1000 & $\begin{array}{c}2000 / 3333 / 5556 \\
\text { tons }\end{array}$ & 20.13 & 9 & 61.35 & 80.51 & 88.56 \\
\hline
\end{tabular}

Note: Smallest jongs in this century is assumed to have a capacity of 50 people, 600-700 people is the average capacity of the Majapahit jong for example those used to attack Singapura, and Majapahit's largest jong can carry 1000 people (Averoes, 2021).

How to confirm the validity of the formula used above? We can compare it to the size of the K'un lun po. From Chinese reports, po ships carrying 600-700 people are larger than $52 \mathrm{~m}$, and those carrying 1000 people are $60 \mathrm{~m}$ or more. Now let's prove it using the same formula. K'un lun Po has a different ratio of passengers to deadweight, which is $1: 1$. From the calculation it is found that:

\begin{tabular}{|c|c|c|c|c|c|c|}
\hline Passenger & $\begin{array}{c}\text { Weight (dead/ } \\
\text { burden/ } \\
\text { displacement) }\end{array}$ & $\begin{array}{c}\text { Width } \\
\text { (waterline) }\end{array}$ & Draft & LWL & LOD & LOA \\
\hline 200 & $200 / 333 / 556$ tons & 11.65 & 3.49 & 27.35 & 35.9 & 39.49 \\
600 & $600 / 1000 / 1667$ tons & 16.81 & 4.71 & 42.08 & 55.22 & 60.74 \\
700 & $700 / 1167 / 1944$ tons & 17.45 & 5.02 & 44.37 & 58.23 & 64.06 \\
1000 & $\begin{array}{c}1000 / 1667 / 2778 \\
\text { tons }\end{array}$ & 18.76 & 5.94 & 49.88 & 65.46 & 72 \\
\hline
\end{tabular}

Note: The po ship with 200 passengers is the one that Fa Hsien boarded (Groeneveldt, 1876: 7), 600-700 people are the average number of K'un lun po passengers, while 1000 people is the largest according to Chinese record (Manguin, 1993a, p. 262).
From the above results, it showed that the result of the calculation is close to the Chinese record. This means that the method that has been used is not wrong. We can also compare the calculations with other scholar estimates. According to Bowring, the length of the ship with a tonnage of 1000 tons is $55 \mathrm{~m}$. From the calculation that has been carried out the results are close (if the tonnage is assigned as burden, not deadweight), that is $55.22 \mathrm{~m}$ LOD. Bowring also mentioned that a jong of 150 tons tonnage would be about $30 \mathrm{~m}$ long. Therefore, another calculation is carried out:

\begin{tabular}{|c|c|c|c|c|c|c|}
\hline Passenger & $\begin{array}{c}\text { Weight (dead/ } \\
\text { burden/ } \\
\text { displacement) }\end{array}$ & $\begin{array}{c}\text { Width } \\
\text { (waterline) }\end{array}$ & Draft & LWL & LOD & LOA \\
\hline 75 & $150 / 250 / 417$ tons & 10.36 & 3.34 & 24.13 & 31.66 & 34.83 \\
\hline
\end{tabular}

The result is that a jong of 150 tons would be about $31.66 \mathrm{~m}$ long LOD, if the tonnage is assumed to be deadweight (assuming the tonnage as burden results in smaller dimensions). Bowring did not mention how he could be sure of the validity of the dimension presented in his book, nor did he mention what type of tonnage it was.

With the validity of my method confirmed, it can be used to calculate other jong or po sizes. For example, we can measure the junk encountered near Pasai (600 tons deadweight). Marco Polo recorded junks of 500-800 tons burden, the weight of which was similar to the weight of the Chinese trade junks used in the 19th century (Wake, December 1997). Niccolò da Conti noted a ship with a burden of 2000 vegetes (Wake, December 1997), or 1300 tons of burden (Lewis, 1973). A Sundanese junk of late 16 th century or early 17 th century that was sunk in Maldives was carrying about 500 person on board. It was seen by François Pyrard of Raval who thought it was the largest ship he has ever seen, with the mast being taller and thicker than those of Portuguese carracks, and the top deck was much larger than those of Portugal (Gray, 1887). The size calculations for these ships would be:

\begin{tabular}{|c|c|c|c|c|c|c|}
\hline Passenger & $\begin{array}{c}\text { Weight (dead/ } \\
\text { burden/ } \\
\text { displacement) }\end{array}$ & $\begin{array}{c}\text { Width } \\
\text { (waterline) }\end{array}$ & Draft & LWL & LOD & LOA \\
\hline 150 & $300 / 500 / 833$ tons & 13.56 & 3.8 & 32.37 & 42.48 & 46.73 \\
240 & $480 / 800 / 1333$ tons & 15.8 & 4.35 & 38.82 & 50.94 & 56.04 \\
300 & $600 / 1000 / 1667$ tons & 16.81 & 4.71 & 42.08 & 55.22 & 60.74 \\
390 & $780 / 1300 / 2167$ tons & 17.88 & 5.27 & 46.03 & 60.4 & 66.44 \\
500 & $1000 / 1667 / 2778$ tons & 18.76 & 5.94 & 49.88 & 65.46 & 72 \\
\hline
\end{tabular}


HISTORIA: Jurnal Pendidik dan Peneliti Sejarah, 5(1), 57-64. https://doi.org/10.17509/historia.v5i1.39181

\section{CONCLUSION}

A study has been carried out on the size of the jong ship. The jong ship in the 16th century is reported to be larger than the Portuguese ship but the exact size is unknown. Irawan Djoko Nugroho's estimate of the jong ship reaching more than $300 \mathrm{~m}$ was declared wrong with the calculations carried out. From the calculation, it is found that the largest jong with a crew of 1000 people would have a displacement of 5556 tons, it would measure $80.51 \mathrm{~m}$ LOD, $88.56 \mathrm{~m} \mathrm{LOA}$, with a width of $20.13 \mathrm{~m}$. This is still below the natural limit for structurally safe wooden ship sizes of 7000 tons displacement and 91.44 $\mathrm{m}$ in length. Other calculations are shown in the tables for measuring the dimension of jongs from different eras.

\section{REFERENCES}

Agius, D.A. (2008). Classic ships of islam: from mesopotamia to the indian ocean. Leiden.

Averoes, M. (2021). Pasang naik dan pasang surut jung jawa [Manuscript submitted for publication]. Department of Mechanical Engineering, Brawijaya University.

Birch, W. G. (1875). The Commentaries of the great afonso dalboquerque, second viceroy of india, translated from the portuguese edition of $1774 \mathrm{vol}$. iii. The Hakluyt society.

Bowring, P. (2019). Empire of the winds: the global role of asia's great archipelago. I. B. Tauris.

Burningham, N. (2019) Shipping of the indian ocean world. In: Schottenhammer A. (Ed.). Early global interconnectivity across the indian ocean world, volume ii. Palgrave Series in Indian Ocean World Studies. Palgrave Macmillan, Cham.

Christie, A. (1957). An obscure passage from the

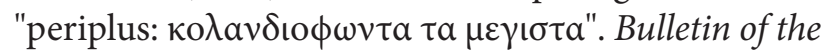
School of Oriental and African Studies, University of London, 19, 345-353.

Church, S.K. (2005). Zheng he: An investigation into the plausibility of $450-\mathrm{ft}$ treasure ships". Monumenta Serica Institute, 53, 1-43.

Cortesão, A. (2017). The suma oriental of tomé pires: an account of the east, from the red sea to japan (Vol. 2). Routledge.

Cortesão, A. (1944b). The suma oriental of tomé pires : an account of the east, from the red sea to japan, written in malacca and india in 1512-1515; and, the book of francisco rodrigues, rutter of a voyage in the red sea, nautical rules, almanack and maps, written and drawn in the east before $1515 \mathrm{vol}$. ii. The Hakluyt Society.
Gray, A. (1887). The voyage of françois pyrard of laval to the east indies, the maldives, the moluccas and brazil vol. i. Hakluyt Society.

Groeneveldt, W. P. (1876). Notes on the malay archipelago and malacca compiled from chinese sources. W. Bruining.

Lewis, A. (December 1973). Maritime skills in the indian ocean 1368-1500". Journal of the Economic and Social History of the Orient, 16(2/3), 238-264.

Leyden, J. (1821). Malay annals translated from the malay language. Longman, Hurst, Rees, Orme, and Brown.

Liebner, H. H. (2016). Beberapa catatan akan sejarah pembuatan perahu dan pelayaran nusantara. Prosiding Konferensi Nasional Sejarah X Jilid II Subtema II. Jakarta, 7-10 November 2016. 1-83.

Major, R. H. (1857). The travels of niccolo conti, in the east, in the early part of te fifteenth century. in india in the fifteenth century: being a collection of narratives of voyages to india, in the century preceeding the portugese discovery of the cape of good hope; from latin, persian, russian, and italian sources, now first translated into english. Hakluyt Society.

Manguin, P. Y. (1993a). Trading ships of the south china sea. Journal of the Economic and Social History of the Orient, 36(3), 253-280.

Manguin, P. Y. (1993b). The vanishing jong: insular southeast asian fleets in trade and war (fifteenth to seventeenth centuries). Dalam Anthony Reid (ed.), Southeast asia in the early modern era: trade, power, and belief (pp.197-213). Cornell University Press

Manguin, P. Y. (2012a). Asian ship-building traditions in the indian ocean at the dawn of european expansion. Dalam Om Prakash, D. P. Chattopadhyaya (Eds.). History of science, philosophy, and culture in indian civilization, volume iii, part 7: the trading world of the indian ocean, 1500-1800 (pp. 597-629). Pearson.

Manguin, P. Y. (2012b). Lancaran, ghurab and ghali. In G. Wade \& L. Tana (Ed.), anthony reid and the study of the southeast asian past (pp. 146-182). ISEAS Publishing.

Manguin, P. Y. (September 1980). The southeast asian ship: An historical approach. Journal of Southeast Asian Studies, 11(2), 266-276.

Meilink-Roelofsz, M. A. P. (1962). Asian trade and european influence in the indonesian archipelago between 1500 and about 1630. The Hague: Martinus Nijhoff.

Mulyana, S. (2005). Runtuhnya kerajaan hindu-jawa dan timbulnya negara-negara islam di nusantara. LKiS Pelangi Aksara.

Murray, W. M. (2012). The age of titans. Oxford University Press.

HISTORIA: Jurnal Pendidik dan Peneliti Sejarah, p-issn:2620-4789 | e-issn:2615-7993 
Nugroho, I. D. (2011). Majapahit peradaban maritim. Suluh Nuswantara Bakti.

Reid, A. (2000). Charting the shape of early modern southeast asia. Silkworm Books.

Rouffaer, G.P. (1915). de eerste schipvaart der nederlanders naar oost-indië onder cornelis de houtman vol. $i$. 'S-Gravenhage M. Nijhoff.

Smyth, H. W. (May 1902). Boats and boat building in the malay peninsula. Journal of the Society of Arts, 1, 570587.

Stanley, H.E. J. (1866). A description of the coast of east africa and malabar in the beginning of the sixteenth century by duarte barbosa. The Hakluyt Society.
Starkey, J. (2007). Natural resources and cultural connections of the red sea. Archaeopress.

Toer, P. A. (1995). Arus balik sebuah epos pasca kejayaan nusantara di awal abad 16. Hasta Mitra.

Wake, C. (December 1997). The great ocean-going ships of southern china in the age of chinese maritime voyaging to india, twelfth to fifteenth centuries. International Journal of Maritime History, 9, 51-81.

Yule, H., \& Burnell, A. C. (1886). Hobson-jobson: being a glossary of anglo-indian colloquial words and phrases and of kindred terms etymological, historical, geographical and discursive. John Murray. 